\title{
The introduction and establishment of Sceliphron caementarium (Drury, I773) (Hymenoptera, Sphecidae) in Malta (Central Mediterranean)
}

\author{
Thomas Cassar', David Mifsud ${ }^{2}$ \\ I Department of Biology, Faculty of Science, University of Malta, Msida MSD 2080, Malta 2 Division of \\ Rural Sciences and Food Systems, Institute of Earth Systems, University of Malta, Msida MSD 2080, Malta \\ Corresponding author: Thomas Cassar (thomas.m.cassar.19@um.edu.mt) \\ Academic editor: M. Ohl | Received 15 September 2020 | Accepted 23 September 2020 | Published 30 October 2020 \\ http://zoobank.org/D1800467-4008-4902-9E99-05672C5F52E0 \\ Citation: Cassar T, Mifsud D (2020) The introduction and establishment of Sceliphron caementarium (Drury, 1773) \\ (Hymenoptera, Sphecidae) in Malta (Central Mediterranean). Journal of Hymenoptera Research 79: 163-168. https:// \\ doi.org/10.3897/jhr.79.58659
}

\begin{abstract}
The introduction and establishment of the North American mud-dauber wasp Sceliphron caementarium (Drury, 1773) is reported for the first time from the Maltese Islands. A check-list of the Maltese Sphecidae is provided.
\end{abstract}

\section{Keywords}

alien, invasive species, Maltese Islands, mud-dauber

\section{Introduction}

Almost 300 species of Hymenoptera are recorded as alien in Europe (Rasplus et al. 2010). Most of these represent either parasitoid taxa (including several aphelinids, eulophids and braconids) of which the majority were deliberately introduced for the biological control of agricultural pests, or invasive ants which were accidentally introduced. 
Table I. Check-list of Sphecidae recorded from the Maltese Islands.

\begin{tabular}{|c|c|}
\hline Species & Notes \\
\hline \multicolumn{2}{|c|}{ Ammophilinae André, 1886} \\
\hline Ammophila heydeni Dahlbom, 1845 & Cilia (1975), Schembri (1991) \\
\hline Podalonia hirsuta (Scopoli, 1763) & Valletta (1971, 1979), Schembri (1991) \\
\hline Podalonia tydei (Le Guillou, 1841) & Schembri (1991) \\
\hline \multicolumn{2}{|c|}{ Sceliphrinae Ashmead, 1899} \\
\hline Sceliphron destillatorium (Illiger, 1807) & Valletta (1971), Schembri (1991) \\
\hline Sceliphron spirifex (Linnaeus, 1758) & Alfken (1929), Erlandsson (1974), Schembri (1991) \\
\hline Sceliphron caementarium (Drury, 1773) & Present work \\
\hline \multicolumn{2}{|c|}{ Sphecinae Latreille, 1802} \\
\hline Prionyx subfuscatus (Dahlbom, 1845) & Valletta (1979), Schembri (1991) \\
\hline Prionyx viduatus (Christ, 1791) & Valletta (1979), Schembri (1991) \\
\hline Prionyx lividocinctus (A. Costa, 1858) & Schembri (1991) \\
\hline Prionyx kirbii (Vander Linden, 1827) & Valletta (1979) \\
\hline Sphex flavipennis Fabricius, 1793 & Erlandsson (1974), Valletta (1979), Schembri (1991) \\
\hline Sphex funerarius Gussakovskij, 1934 & Valletta (1971), Erlandsson (1974) \\
\hline Sphex pruinosus Germar, 1817 & Erlandsson (1974), Schembri (1991) \\
\hline
\end{tabular}

Six species of the family Sphecidae are present as aliens in Europe, three of which belong to genus Sceliphron Klug, 1801 (Schmid-Egger and Herb 2018). This genus currently contains 35 species globally, only four of which are native to Europe and the Mediterranean (Schmid-Egger 2005; Pulawski 2020). Species of Sceliphron are readily identified by their thin and elongated petiole, generally dark body colour - either black or reddish - contrasted against by various yellow maculations, and propodeal enclosure: the propodeal dorsum is delimited by a distinct groove; a generic description is available in Bohart and Menke (1976). The nests of Sceliphron are constructed out of mud, collected and carried by females in the form of globules from the collection site; the nest is multilocular and attached to various surfaces (often the walls of buildings) and is provisioned with spiders (Arachnida: Araneae) on which larvae feed (Bohart and Menke 1976).

Only two species of Sceliphron were recorded from the Maltese Islands in the past: Sceliphron spirifex (Linnaeus, 1758) originally recorded by Alfken (1929) and Sceliphron destillatorium (Illiger, 1807) originally recorded by Valletta (1971).

In the present work we provide evidence for the introduction and subsequent establishment of the North American mud-dauber wasp Sceliphron caementarium (Drury, 1773) in Malta, bringing the total number of Sphecidae from the Maltese Islands to thirteen (Table 1).

\section{Methods}

The material examined consists of four specimens reared from a mud nest collected in Malta. Identification was carried out using the work of Schmid-Egger (2005). A photograph of this species taken in Malta was also taken into account for the following reasons; (i) all characters to identify it to species level were available and (ii) all collection data were available. 


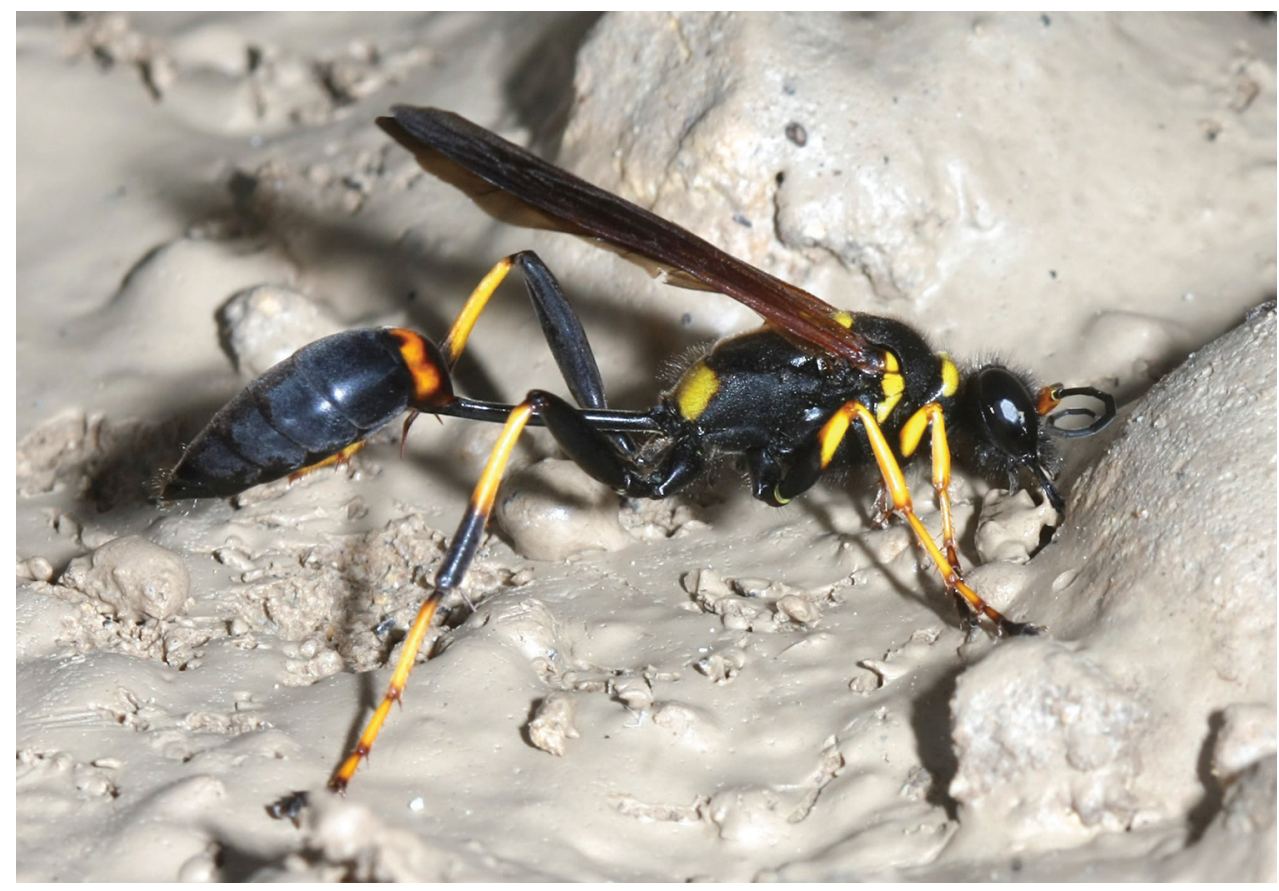

Figure I. Female Sceliphron caementarium collecting mud in H'Attard, Malta.

\section{Results}

\section{Sceliphron caementarium (Drury, 1773)}

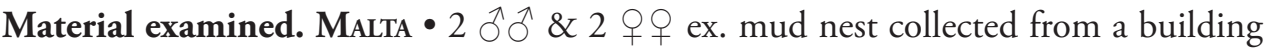
wall; Hal Tarxien; Dec. 2019, emerged Jun. 2020; D. Mifsud leg. 19 photographed collecting mud; H'Attard; 31 Aug. 2018; V. Falzon leg. (Fig. 1).

Both the photographed and examined specimens conform well to the diagnosis of S. caementarium provided by Schmid-Egger (2005). The overall colour is black; the scutellum, post-scutellum, tegulae and mesopleura are marked with yellow; the antennal scapes are yellow; the propodeum is marked with a yellow spot just before the petiole; tergite 1 is marked with dark yellow; the legs are marked with yellow and black; the petiole is straight and completely black; the wings are brown, becoming more infuscate in the distal half; and the hind coxa bulges in a rounded manner.

\section{Discussion}

With a native distribution ranging over much of North America, Sceliphron caementarium can be recognised as a Nearctic species in origin. It started spreading outside its native range to various isolated islands in the Pacific, and Madeira in the Atlantic; then Australia, Asia (Japan) and Europe, and the species has also been inter- 
cepted in New Zealand (Harris 1992). In the Atlantic it was also recorded from the Canary Islands (Erlandsson 1977). In Europe, S. caementarium was first recorded in the Czech Republic in 1942 (Bogusch and Macek 2005) and never recorded again in that region; three years later it was also recorded in France (Berland 1946) however this record represented another isolated introduction as it was not recorded from France for another thirty years (Leclercq 1975). The North American species did not become truly established in Europe until the later years of the 1970s - for example, in the Iberian Peninsula (Leclercq 1975); since then it established itself in various other regions such as Austria (Gusenleitner 2002) and Italy (Pagliano 1992) among others; more recently it has been recorded from Bulgaria (Gradinarov 2017), Belgium (Ravoet et al. 2017) and the Balearic Islands (Díaz-Calafat 2020). Thus it can be said that this North American species did not establish itself in Europe until the later years of the 1970s, and reached the Mediterranean basin soon thereafter.

The discovery of Sceliphron caementarium in Malta comes as no surprise; it has recently established itself in the nearby island of Sicily, and mud-dauber wasps of this genus are well-known for their dispersal ability, arriving in new regions via nests attached to marine vessels and transportation vehicles (Turrisi and Altadonna 2017). The possible effect of $S$. caementarium on the native Sceliphron species in the Maltese Islands, namely $S$. spirifex and $S$. destillatorium, remains to be seen. In the French region of Provence, Piek (1986) showed that the alien S. caementarium had probably surpassed the native $S$. spirifex in number, possibly outcompeting it. Campadelli et al. (1999) noted that, in the Italian region of Emilia-Romagna, far more nests of the introduced $S$. caementarium were collected than native $S$. destillatorium. The similar biology of $S$. caementarium to other Sceliphron and its polyphagy may represent a competitive threat for native Sceliphron in Malta, especially in the insular environment of such a small archipelago. However, the effect of this introduced species can only be determined with certainty by monitoring its presence in the islands and longterm data collection.

\section{Conclusion}

The above cited material provides the first documentation of the introduction and establishment of the North American mud-dauber wasp, Sceliphron caementarium in the Maltese Islands. This record extends the distribution range of this species in southernmost Europe.

\section{Acknowledgements}

The authors would like to thank Mr Victor Falzon (Malta) for allowing the use of his photograph. The authors are also grateful to Dr Andrew Polaszek (The Natural History Museum, London, UK) for reviewing the present work. The authors have no funding to report. The authors have declared that no competing interests exist. 


\section{References}

Alfken JD (1929) Ueber eine Hymenopteren-Ausbeute von Malta. Mitteilungen aus dem entomologischen Verein Bremen. 15.-17. Bericht für die Jahre 1927-1929: 9-11.

Berland L (1946) Capture énigmatique d'une guêpe américaine à Versailles. L'Entomologiste 2: $227-228$.

Bohart RM, Menke AS (1976) Sphecid wasps of the world. A generic revision. University of California Press, Berkeley, Los Angeles, London, [1 color plate, IX +] 695 pp.

Campadelli G, Pagliano G, Scaramozzino PL, Strumia F (1999) Parassitoidi e inquilini di Sceliphron caementarium (Drury, 1773) (Hymenoptera: Sphecidae) in Romagna. Bollettino del Museo Regionale di Scienze Naturali di Torino 16: 225-240.

Cilia J (1975) Insect visitors to the seaside squill (Urginea maritima (L.) Baker). The Maltese Naturalist 2(2): 37-38.

Díaz-Calafat J (2020) Primer registro de Sceliphron caementarium (Drury, 1773) (Hymenoptera: Sphecidae) en las Islas Baleares, con una clave de identificación para las especies del archipiélago del género Sceliphron Klug, 1801. Ecosistemas 29(1): e1939. https://doi. org/10.7818/ECOS.1939

Erlandsson S (1974) Hymenoptera Aculeata from the European parts of the Mediterranean Countries. Eos, Madrid 48: 11-93.

Erlandsson S (1977) Notes of aculeate Hymenoptera from the Macaronesian Islands. Vieraea: Folia scientarum biologicarum canariensium 7: 201-206.

Gradinarov D (2017) First records of the American wasps Sceliphron caementarium (Drury, 1770) and Isodontia mexicana (de Saussure, 1867) (Hymenoptera: Sphecidae) from Bulgaria. ZooNotes 118: 1-4.

Gusenleitner J (2002) Hymenopterologische Notizenaus Österreich - 15 (Insecta: Hymenoptera aculeata). Linzer Biologische Beiträge 34(2): 1123-1126.

Harris AC (1992) Wasps of the genus Sceliphron (Hymenoptera: Sphecidae) intercepted in New Zealand. New Zealand Entomologist 15(1): 39-42. https://doi.org/10.1080/00779962.1 992.9722627

Leclercq J (1975) Sceliphron caementarium (DRURY) s'établit en Europe (Hymenoptera Sphecidae). Bulletin des Recherches Agronomiques de Gembloux (Nouvelle Serie) 10: 371.

Pagliano G (1992) Scheliphron caemetarium (Drury, 1773) (Hymenoptera Sphecidae) specie nuova della penisola italiana. Hy-Men 3: 5.

Piek T (1986) Sceliphron caementarium (Drury) supersedes $S$. spirifex Linnaeus in the Provence, France (Hymenoptera, Sphecidae). Entomologische Berichten 46: 77-79.

Pulawski WJ (2020) Catalog of Sphecidae sensu lato (= Apoidea excluding Apidae). California Academy of Sciences, San Francisco. https://www.calacademy.org/scientists/projects/ catalog-of-sphecidae [accessed July 7, 2020]

Rasplus J-Y, Villemant C, Rosa Paiva M, Delvare G, Roques A (2010) Hymenoptera. Chapter 12. BioRisk 4: 669-776. https://doi.org/10.3897/biorisk.4.55

Ravoet J, Barbier Y, Klein W (2017) First observation of another invasive mud dauber wasp in Belgium: Sceliphron caementarium (Drury, 1773) (Hymenoptera: Sphecidae). Bulletin de la Société royale belge d'Entomologie 153: 40-42. 
Schembri S (1991) Sphecids wasps of the Maltese Islands. A review. Bollettino della Società Entomologica Italiana 122(3): 175-184.

Schmid-Egger C (2005) Sceliphron curvatum (F. Smith 1870) in Europa mit einem Bestimmungsschlüssel für die europäischen und mediterranen Sceliphron-Arten (Hymenoptera, Sphecidae). Bembix 19(2005): 7-28.

Schmid-Egger C, Herb G (2018) Ein weiterer Nachweis von Chalybion californicum (de Saussure, 1867) in Europa (Hymenoptera, Sphecidae). Ampulex 10: 35-37.

Turrisi GF, Altadonna G (2017) A report on two alien invasive species of the genus Sceliphron Klug, 1801 (Hymenoptera Sphecidae) from Sicily, with a brief faunistic update on the native species. Biodiversity Journal 8(2): 753-762.

Valletta A (1971) A preliminary list of the Hymenoptera Aculeata (excluding ants) of the Maltese Islands. Entomologist's Monthly Magazine 107: 45-46.

Valletta A (1979) Second contribution to the Hymenoptera Aculeata (excluding ants) of the Maltese Islands. Entomologist's Monthly Magazine 114: 215. 